\title{
Effect of mesh size on baited trap catch composition for noble crayfish (Astacus Astacus)
}

\author{
S.I. Johnsen ${ }^{(1), \star}$, J. Skurdal(1), T. Taugbø|(2), E. Garnås( ${ }^{(3)}$
}

Received December 17, 2013

Revised March 13, 2014

Accepted March 17, 2014

Key-words: trap selection, minimum size, noble crayfish

\section{ABSTRACT}

Minimum size is a common management regulation in noble crayfish (Astacus astacus) fisheries. The most used catching method baited traps, catch crayfish down to $50 \mathrm{~mm}$ total length (TL). In Norway the minimum size is $95 \mathrm{~mm}$ TL and this regulation allow female crayfish to spawn a least once before being harvested. To reduce the fraction of non-legal sized crayfish in trap catches, mesh-size were increased from 17.5 to $21 \mathrm{~mm}$ (knot to knot) in Lake Steinsfjorden (1983) and nationwide (2001). We compared catch per unit effort data in traps with different mesh sizes from the two most important noble crayfish fisheries in Norway to evaluate the effects of the regulation. Traps with mesh size $21 \mathrm{~mm}$ catch significantly fewer crayfish compared to traps with $17.5 \mathrm{~mm}$ and $12 \mathrm{~mm}$. As intended, traps with $21 \mathrm{~mm}$ caught significantly less non-legal sized crayfish compared to $17.5 \mathrm{~mm}$. Increased mesh size thus reduce the catch-induced mortality of non-legal sized crayfish, resulting in a larger spawning population. Mesh size regulations is an important management tool, especially for recruitment limited crayfish population, and is rather easy to enforce compared to minimum size.

\section{RÉSUMÉ}

Effet de la taille des mailles de nasses appâtées sur la composition des captures de l'écrevisse à pattes rouges (Astacus astacus)

Mots-clés : sélectivité de piège, taille minimum, écrevisse à pattes rouges
La taille minimale est un règlement de gestion commun de la pêche de l'écrevisse à pattes rouges (Astacus astacus). La méthode de capture la plus utilisée, les nasses appâtées, capture des écrevisses de longueur totale minimum allant jusqu'à $50 \mathrm{~mm}$. En Norvège, la taille minimale est de $95 \mathrm{~mm}$ de longueur totale $(T L)$ et l'actuel règlement permet à l'écrevisse femelle de se reproduire au moins une fois avant d'être capturée. Pour réduire la fraction de l'écrevisse de taille non légale dans les prises des nasses, le maillage a été augmenté de 17,5 à $21 \mathrm{~mm}$ (nœud à nœud) dans le lac Steinsfjorden (1983) et à l'échelle nationale (2001). Nous avons comparé les données des prises par unité d'effort dans les pièges avec différents maillages dans les deux plus importantes pêcheries d'écrevisse à pattes rouges en Norvège pour évaluer les effets de la réglementation. Les nasses d'un maillage de $21 \mathrm{~mm}$ capturent significativement moins d'écrevisses comparées aux nasses avec un maillage de $17,5 \mathrm{~mm}$ et $12 \mathrm{~mm}$. Comme prévu, les nasses de $21 \mathrm{~mm}$ capturent beaucoup moins d'écrevisses de taille non légale par rapport

(1) Norwegian Institute of Nature Research, 2624 Lillehammer, Norway

(2) The GLB Water Management Association, P.O. Box 1209, 2605 Lillehammer, Norway

(3) Buskerud County Environmental Administration, 3007 Drammen, Norway

* Corresponding author: stein.ivar.johnsen@nina.no 
à celles de 17,5 mm. L'augmentation de la taille des mailles réduit ainsi la mortalité induite par capture des écrevisses de taille non légale, résultant en une plus grande population reproductrice. La réglementation des maillages est un outil de gestion important, en particulier pour le recrutement de populations d'écrevisses réduites, et est assez facile à appliquer comparé à la taille minimale.

\section{INTRODUCTION}

Stocks of noble crayfish (Astacus astacus) are frequently heavily exploited in Scandinavia and thus it is necessary to develop management tools that can regulate the level of exploitation. Crayfish are vulnerable to exploitation due to their high susceptibility to baited traps. Noble crayfish are recognised as vulnerable by the European Union (EU) Habitat Directive and is a species that needs special management schemes. The species is also included in international (IUCN, 1996) and national (Kålås et al., 2010) red lists. It has been argued that the possibility for exploitation and economical as well as recreational benefits among local inhabitants may increase the interest for conservation (Taugbøl, 2004; Jones et al., 2006; Zimmerman, 2012). This implies that the management of noble crayfish needs to consider carefully the balance between conservation and utilisation.

Minimum size is a common management regulation in noble crayfish fisheries (Skurdal and Taugbøl, 2002). The most used catching method; baited traps catch crayfish down to $50 \mathrm{~mm}$ total length (TL) (Abrahamsson, 1966; Qvenild and Skurdal, 1987; Huner et al., 1991). In Norway the minimum size is $95 \mathrm{~mm}$ TL which allow female crayfish to spawn a least once before harvested (Skurdal et al., 2002). However as minimum size is difficult to enforce since it involves checking a number of fishermen individually during the fishing season, gear restriction to reduce the catch of small crayfish could be an important management tool.

Mesh size of baited traps affect size composition and increased mesh size of traps can be used to reduce the fraction of non-legal sized crayfish in catches. This method is favourable as it is more efficient to enforce mesh size of baited traps than the minimum size itself. In Lake Steinsfjorden, Norway, non-legal sized crayfish suffered a mortality of at least 10-20\% due to handling stress, consumption and translocation to other localities (Qvenild and Skurdal, 1986). To reduce the mortality of non-legal crayfish, mesh size of baited traps were increased from 17.5 to $21 \mathrm{~mm}$ in 1983. Both laboratory and field experiments showed that increased mesh size could reduce fraction of non-legal sized crayfish in trap catches (Qvenild and Skurdal, 1987). However, fractions are sensitive to e.g. year-class fluctuations and direct or an indirect measurement of abundance is to be preferred to achieve a more precise description of the effect.

In this work, we evaluate differences in crayfish size composition and relative size-specific abundance of crayfish in traps with different mesh size from two different lakes. Further, we discuss the effect of mesh size on size composition and as a management tool in heavy exploited crayfish fisheries.

\section{MATERIAL AND METHODS}

\section{> STUDY LOCALITIES}

Lake Steinsfjorden and Lake Einafjorden are the two most important noble crayfish localities in Norway, with a total harvest of about three tonnes annually. Both lakes have good conditions for crayfish, with $10-15 \mathrm{mg} \mathrm{Ca} \cdot \mathrm{L}^{-1}$ and $\mathrm{pH}$ above $=7.0$. Both lakes have large areas with stony bottom substrate, providing good shelter for all size groups of crayfish in the littoral zone (Skurdal et al., 1993; Johnsen and Taugbøl, 2008). 
Table I

Effort and number of crayfish caught before and after the fishing season in traps with different mesh size in the years 1988-2008.

\begin{tabular}{|l|c|c|c|c|}
\cline { 2 - 5 } \multicolumn{1}{c|}{} & \multicolumn{2}{c|}{ Pre-season } & \multicolumn{2}{c|}{ Post-season } \\
\cline { 2 - 5 } \multicolumn{1}{c|}{} & $17.5 \mathrm{~mm}$ & $\mathbf{2 1} \mathrm{mm}$ & $17.5 \mathrm{~mm}$ & $21 \mathrm{~mm}$ \\
\hline Effort (trap nights) & 1255 & 393 & 1247 & 385 \\
\hline Number of crayfish & 13820 & 2274 & 11403 & 1451 \\
\hline
\end{tabular}

\section{> DATA SAMPLING}

In Lake Steinsfjorden, noble crayfish were sampled annually from both pre- and post-season test fishing. The sampling was performed with baited one-funnel traps in the 1-10 m depth areas on an $1100 \mathrm{~m}$ stretch on the eastern shore of the lake. The traps, with mesh size 17.5 and $21 \mathrm{~mm}$ (knot to knot), were randomly mixed and set individually in the evening and emptied the next morning (Skurdal et al., 1993). The minimum distance between individual traps were $10 \mathrm{~m}$. The one-funnel traps used in Lake Steinsfjorden were developed from local fishermen, and the continued use of these traps, in contrast to the more common two-funnel LINI traps, have been done to ensure comparisons in catches throughout the period. As traps were baited in the same way and set randomly over an $1100 \mathrm{~m}$ shoreline, unequal effort in the number of traps with different mesh sizes is not expected to influence the catches.

The pre- and post-season test fishing was performed at the same period each year. From the years 1988-2008, we recorded effort (traps night ${ }^{-1}$ ), the total number of crayfish and individual TL in each mesh size separately (see Skurdal et al., 1993 and Table I for more details). From this, we calculated the number of both non-legal sized $(<95 \mathrm{~mm} \mathrm{TL})$ and legal sized crayfish (>94 mm TL) per trap night (CPUE) in order to evaluate the effect of increased mesh size on the size structure of harvested crayfish. In Lake Einafjorden, an experiment to evaluate the size composition of noble crayfish in traps with 12 and $21 \mathrm{~mm}$ were conducted in 2005. A total of 40 traps (20 of each mesh size) were set alternating along the shoreline in the evening and emptied the next morning. Size and number of crayfish were recorded for each mesh size separately. From this, we calculated the CPUE of both non-legal sized and legal sized crayfish. Differences in CPUE from different mesh sizes were analysed by Kruskal-Wallis one-way ANOVA with pairwise comparisons (Tuckey test). We also used chi-square statistics to test differences in the odds of 17.5 or $21 \mathrm{~mm}$ mesh size having the highest CPUE values within a given year.

\section{RESULTS}

In Steinsfjorden, a total of 16.094 crayfish were caught in baited traps (1.648 trap nights) in the pre-season test fishing (29 July-6 August) 1988-2008, and 12.854 crayfish (1.632 trap nights) in the post-season test fishing (20 September-27 October) 1988-2008 (see Table I). There were significantly more non-legal sized crayfish in traps with $17.5 \mathrm{~mm}$ than in traps with $21 \mathrm{~mm}$ both in pre- and post-season catches $(p<0.05$, Figure 1). For legal sized crayfish, no significant differences were found in CPUE between mesh sizes (Figure 2). However, it was 6.3 (95\% C.I.: $\left.2.4-16.1 ; \chi^{2}=13.8, p<0.001\right)$ times more likely that traps with $17.5 \mathrm{~mm}$ mesh size had higher CPUE values of legal sized crayfish compared to traps with $21 \mathrm{~mm}$ mesh size within a given year. Due to high exploitation, the catches of legal sized crayfish are significantly lower in traps with both mesh sizes after the fishing season $(p<0.05$, Figure 2$)$. In Lake Einafjorden, 20 baited traps yielded a total of 439 and 275 noble crayfish in 12 and $21 \mathrm{~mm}$ mesh size respectively, and the catches with $12 \mathrm{~mm}$ mesh size were significantly higher than in traps with $21 \mathrm{~mm}(p<0.05$, Figure 3a). The fraction of legal sized crayfish in the catches from $21 \mathrm{~mm}$ traps were much higher (63.3\%) than in traps with $12 \mathrm{~mm}(48.7 \%)$. However, the total CPUE of legal sized crayfish were higher in $12 \mathrm{~mm}\left(\mathrm{CPUE}_{\text {legal sized }}=107\right.$ ) than in $21 \mathrm{~mm}\left(\right.$ CPUE $\left._{\text {legal sized }}=8.8\right)$ traps. A plot of "remaining" CPUE of each mesh size 


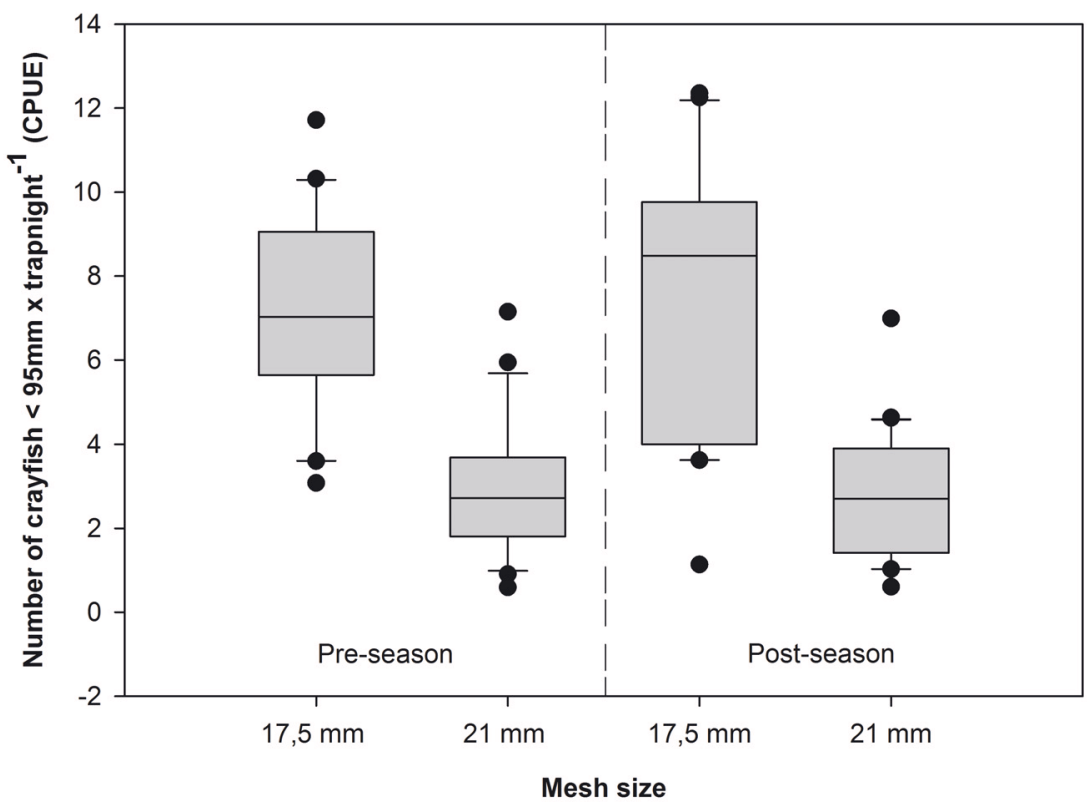

Figure 1

Boxplot comparing the number of non-legal sized crayfish $\times$ trapnight $^{-1}$ (CPUE) in traps with 17.5 and $21 \mathrm{~mm}$ mesh size in pre- and post-season catches from the years 1988-2008.

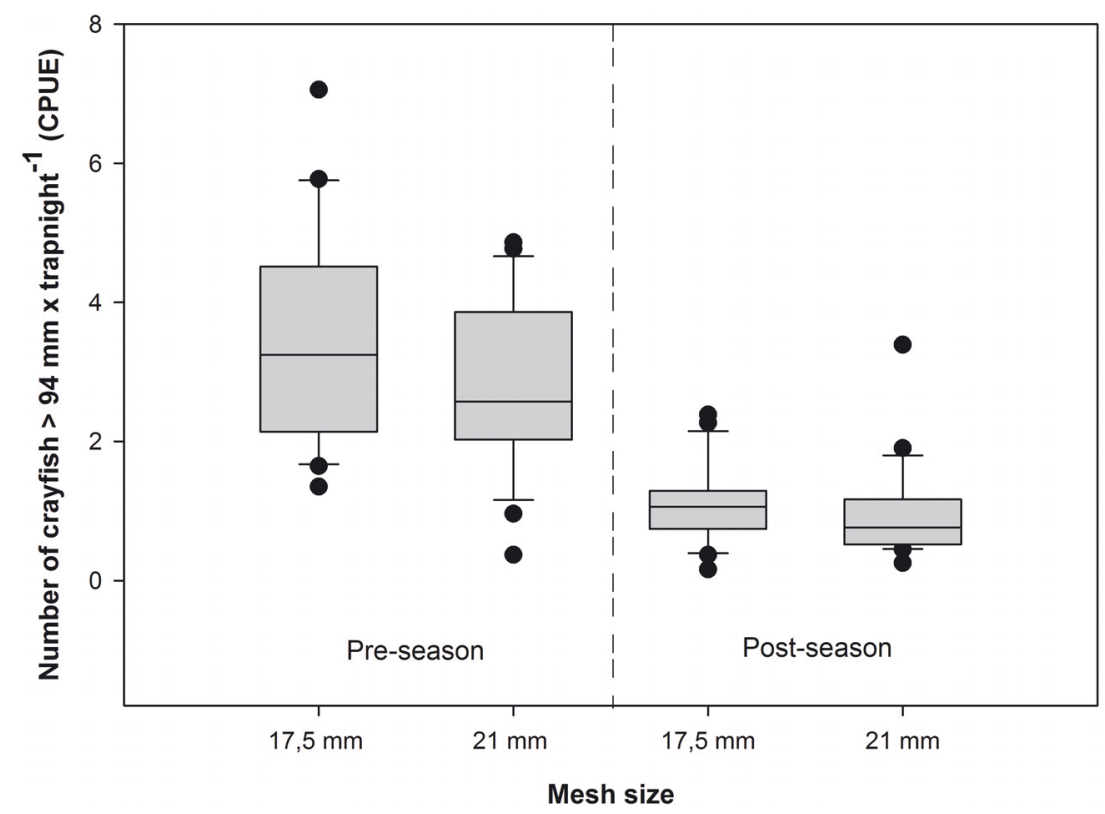

Figure 2

Boxplot comparing the number of legal sized crayfish $\times$ trapnight $^{-1}$ (CPUE) in traps with 17.5 and $21 \mathrm{~mm}$ mesh size in pre- and post-season catches from the years 1988-2008.

against length, visualize that traps with $12 \mathrm{~mm}$ mesh size have a higher total CPUE of crayfish up to about $100 \mathrm{~mm}$ (Figure $3 b$ ).

\section{DISCUSSION}

Noble crayfish has for centuries been subjected to exploitation due to its reputation as a delicacy and the high prices obtained in the market. Despite the long history of exploitation 

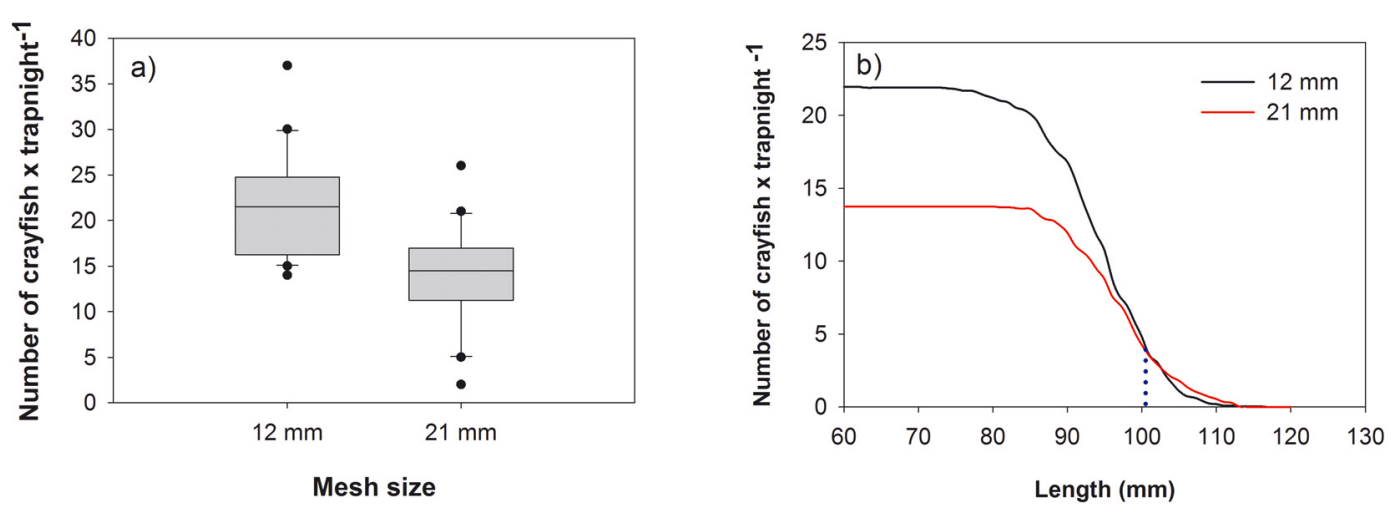

Figure 3

Boxplot comparing the number of crayfish $\times$ trapnight $^{-1}$ (CPUE) in traps with $12(\mathrm{~N}=20)$ and $21 \mathrm{~mm}$ $(N=20)$ mesh size (a), and a subtracting curve (b) displaying the CPUE of crayfish larger than a given length (b).

in Europe and the considerable commercial interest, little is known about optimal management of wild populations and published data gives conflicting results and recommendations regarding harvest strategies (Westman 1991, 1992; Fiskeriverket, 1998). The legislation varies between countries and this variation partly reflects differences in crayfish catching traditions (Westman, 1991; Skurdal and Taugbøl, 1994, 2002). Most of the harvested crayfish populations in Europe are managed through a variety of direct and indirect regulations, of which various minimum sizes and trapping seasons are the most important (Westman et al., 1990; Skurdal and Taugbøl 1994, 2002; Skurdal et al., 2002, 2013). The legal trapping season for noble crayfish varies considerably, and may last from a few days to several months and also differs between males and females (Westman et al., 1990; Skurdal and Taugbøl, 1994, 2002).

Catching crayfish differs from the harvests of most other natural species since all crayfish are caught alive and the catch may be sorted according to size or sex, and even maturity, if necessary. Even if some mortality may occur due to handling stress (Qvenild and Skurdal, 1986), mortality rates of crayfish that are released after being caught is probably very low if they are properly handled. Complex regulations, including protection of selected portions of the population, are thus a possibility. When modelling crayfish population dynamics based on data gathered from Lake Steinsfjorden, management strategies, including saving the largest individuals and slot limits, have been proposed based on harvest output (Sadykova et al., 2009, 2011). However control and enforcement is a general problem with these types of regulations. Thus, the most favourable management scheme has to fulfil a number of requirements, such as being understandable and having broad acceptance among the various user groups. The regulation must also be easy to control and, give necessary protection of the stocks, as well as allow for an optimal harvest. Thus, any management scheme for crayfish has to consider both biological and social issues in order to be successful (Skurdal et al., 2002; Taugbøl, 2004).

As female noble crayfish mature at $70-90 \mathrm{~mm}$ total length (Taugbøl et al., 1988) it is important to have regulations which allow females to spawn at least once before being caught. A minimum size of $95 \mathrm{~mm}$ TL is sufficient to protect small crayfish; however it is very laborious and expensive to control the catches to ensure that the minimum size limit is respected. The results from test fishing in Lake Steinsfjorden and Lake Einafjorden demonstrate that mesh size of baited traps is a useful tool to reduce catch of non-legal sized crayfish. There were significantly more non-legal sized crayfish in traps with $17.5 \mathrm{~mm}$ than in traps with $21 \mathrm{~mm}$ both in pre- and post-season catches. Even though it is possible to sort the catch of noble crayfish both according to size and sex, using gear that reduces the fraction of smaller crayfish is recommended to avoid increased mortality from translocation, consumption and handling stress. The experience from Lake Steinsfjorden was that some fishermen probably consumed small-sized crayfish themselves and some translocated small crayfish to other 
areas and lakes were they had more exclusive right to trapping crayfish (Qvenild and Skurdal, 1986). Crayfish traps are emptied during daytime and the fishermen use several hours to empty their traps, due to sun exposure mortality of small-sized crayfish increase. Increased mesh size adapted to the local minimum legal size is therefore recommended as a tool to reduce mortality and non-legal catching of small crayfish. Our results also suggest that the smallest legal sized crayfish (95-100 mm TL) are able to escape through the meshes of traps with $21 \mathrm{~mm}$. This implicates that the mortality of legal sized crayfish from harvest also will be reduced. In Lake Steinsfjorden the county governor has increased the baited trap mesh size to $23 \mathrm{~mm}$ (knot to knot) from 2013. This will most likely reduce the harvest rate of legal sized crayfish further, and will be evaluated in the years to come.

An alternative to increased mesh size is the use of escape gaps known from marine crustacean fisheries which have been successfully implemented to reduce undersized catch (Linnane et al., 2012). In Swedish public waters, the fishing administration has been adapting regulations and introduced the trap gaps to the inland signal crayfish (Pacifastacus leniuscuIus Dana) fisheries, with the intention to let undersized (100 mm TL or smaller) signal crayfish escape. The catch of undersized females was found to be lower in traps with escape gaps, even at a length where the females should be physically restricted from escaping by the width of their tail (Andersson et al., 2012). Since it is very laborious to change the mesh size of traps, this should also be tested as an alternative method for noble crayfish.

To conclude, mesh size is an important management tool in noble crayfish fisheries and a mesh size of at least $21 \mathrm{~mm}$ (knot to knot) is recommended when the minimum size is $95 \mathrm{~mm}$ TL.

\section{ACKNOWLEDGEMENTS}

During the study period we have received valuable help from a number of people. We are grateful for help from Terje Steinsæther, Truls Kristensen and Kjell Sundøen. The study has received financial support from the Directorate for Nature Management, the Norwegian Institute of Nature Research and the County Governor in Buskerud.

\section{REFERENCES}

Abrahamsson S.A.A., 1966. Dynamics of an isolated population of Crayfish, Astacus astacus Linné. Oikos, 17, 96-107.

Andersson M., Johansson M., Persson J. and Edsman L., 2012. Evaluation of the potential of escape gaps to improve the selectivity in freshwater crayfish fisheries. In: IAA Book of abstracts, Innsbruck, Austria, 8.

Fiskeriverket, 1998. Möjligheter att öka flodkräftbestånd i svenska vatten. Inf. Sötvattenslab. Drottningholm (In Swedish).

Huner J.V., Henttonen P. and Lindqvist O.V., 1991. Observations on noble crayfish, Astacus astacus Linneaeus, (Decapoda, Astacidae), populations in central Finland - management implications. J. Shellfish Res., 10, 187-193.

IUCN, 1996. IUCN red list of threatened animals. IUCN, Washington, DC.

Johnsen S.I. and Taubøl T., 2008. Add stones, get crayfish - Is it that simple? Freshw. Crayfish, 16, 47-50.

Jones J.P.G., Andriahajaina F.B., Ranambinintsoa E.H., Hockley N.J. and Ravoahangimalala O., 2006. The economic importance freshwater crayfish harvesting in Madagascar and the potential of community-based conservation to improve management. Oryx, 40, 168-175.

Kålås J.A., Viken Å., Henriksen S. and Skjelseth S., (eds.) 2010. The 2010 Norwegian Red List for Species. Norwegian Biodiversity Information Centre, Norway, $480 \mathrm{p}$.

Linnane A., Penny S., Hoare M. and Hawthorne P., 2011. Assessing the effectiveness of size limits and escape gaps as management tools in a commercial rock lobster (Jasus edwardsii) fishery. Fish. Res., 111, 1-7. 
Qvenild T. and Skurdal J., 1986. The yield of a heavily exploited population of Astacus astacus in Lake Steinsfjorden, S. E. Norway. Freshwater Crayfish, 6, 194-198.

Qvenild T. and Skurdal J., 1987. Does increased mesh size reduce nonlegalsized fraction of Astacus astacus in trap catches? Freshw. Crayfish, 7, 277-284.

Sadykova D., Skurdal J., Sadykov A., Taugbøl T. and Hessen D.O., 2009. Modelling crayfish population dynamics using catch data: A size-structural model. Ecol. Model., 220, 2727-2733.

Sadykova D., Skurdal J., Hessen D.O. and Schweder T., 2011. Saving the largest makes a difference: exploring effects of harvest regulations by model simulations for noble crayfish, Astacus astacus L. Fisheries Manag. Ecol., 18, 307-313.

Skurdal J. and Qvenild T., 1986. Growth, maturity, and fecundity of Astacus astacus in Lake Steinsfjorden, S.E. Norway. Freshw. Crayfish, 6, 182-186.

Skurdal J. and Taugbøl T., 1994. Do we need regulations for catching crayfish? Rev. Fish Biol. Fisher., 4, 461-485.

Skurdal J. and Taugbøl T., 2002. Astacus. In: Holdich D.M. (ed.), Biology of Freshwater Crayfish, Blackwell Science, Oxford, England, 467-510.

Skurdal J., Qvenild T., Taugbøl T. and Garnås E., 1993. Long term study of exploitation, yield and stock structure of noble crayfish Astacus astcus in Lake Steinsfjorden. Freshw. Crayfish, 9, 118-133.

Skurdal J., Garnås E. and Taugbøl T., 2002. Management strategies, yield and population devlopment of the noble crayfish Astacus astacus in Lake Steinsfjorden. Bull. Fr. Pêche Piscic., 367, 845-860.

Skurdal J., Johnsen S.I. and Garnås E., 2013. Adaptive management of noble crayfish (Astacus astacus). Freshw. Crayfish, 19, 145-151.

Taugbøl T., 2004. Exploitation is a prerequisite for conservation of A. astacus. Bull. Fr. Pêche Piscic., 372-373, 275-279.

Taugbøl T., Skurdal, J. and Fjeld, E. 1988. Maturity and fecundity of Astacus astacus females in Norway. Freshw. Crayfish, 7, 107-114.

Westman K., 1991. The crayfish fishery in Finland - its past, present and future. Finn. Fisheries Res., 12, 187-216.

Westman K., 1992. Management of the noble crayfish Astacus astacus (L.) and the signal crayfish Pacifastacus leniusculus (Dana) in Finland. Finn. Fisheries Res., 14, 19-51.

Westman K., Pursianinen M. and Westman P., 1990. Status of crayfish stocks, fisheries, diseases and culture in Europe. Report of the FAO European Inland Fisheries Advisory Commission (EIFAC) Working Party on Crayfish. Finnish Game and Fisheries Research Institute Report No. 3, 1990, Helsinki, Finland.

Zimmerman J.K.M., 2012. Noble crayfish (Astacus astacus) in a changing world - implications for management. Doctoral Thesis. Mid Sweden University, Sundsvall, Sweden. 